Article

\title{
Anticancer Profiling for Coumarins and Related $O$-Naphthoquinones from Mansonia gagei against Solid Tumor Cells In Vitro
}

\author{
Mohammed A. Baghdadi ${ }^{1,2}$ (1) , Fahad A. Al-Abbasi ${ }^{1}$, Ali M. El-Halawany ${ }^{3,4}$, Ali H. Aseeri ${ }^{5}$ \\ and Ahmed M. Al-Abd 4,6,* iD \\ 1 Department of Biochemistry, Faculty of Science, King Abdulaziz University, Jeddah 21589, Saudi Arabia; \\ m-baghdadi@hotmail.com (M.A.B.); alabassif@hotmail.com (F.A.A.-A.) \\ 2 Research Centre, King Faisal Specialist Hospital \& Research Centre, Jeddah 21499, Saudi Arabia \\ 3 Pharmacognosy Department, Faculty of Pharmacy, Cairo University, Cairo 11562, Egypt; \\ ahalawany2003@yahoo.com \\ 4 Stem Cell Research Unit, King Fahad Medical Research Center, King Abdulaziz University, \\ Jeddah 21589, Saudi Arabia \\ 5 Ministry of Health, Jeddah 21484, Saudi Arabia; alhaseeri@moh.gov.sa \\ 6 Department of Pharmacology, Medical Division, National Research Centre, Cairo 12622, Egypt \\ * Correspondence: ahmedmalabd@pharma.asu.edu.eg or amalabd@kau.edu.sa; Tel.: +966-(0)2-640-0000 (ext. 21125)
}

Received: 29 March 2018; Accepted: 21 April 2018; Published: 26 April 2018

\begin{abstract}
Napthoquinones and coumarins are naturally occurring compounds with potential anticancer activity. In the current study, two $O$-naphthoquinons (mansonone- $\mathrm{G}$ and mansonone-N) and six coumarins (mansorin-A, mansorin-B, mansorin-C, mansorins-I, mansorin-II, and mansorin-III) were isolated from the heartwood of Mansonia gagei family Sterculariaceae. Isolated compounds were examined for their potential anticancer activity against breast (MCF-7), cervix (HeLa), colorectal (HCT-116) and liver (HepG2) cancer cells using Sulfarhodamine-B (SRB) assay. Mansorin-II and mansorin-III showed relatively promising cytotoxic profile in all cell lines under investigation with inhibitory concentrations $\left(\mathrm{IC}_{50} \mathrm{~s}\right.$ ) in the range of $0.74 \mu \mathrm{M}$ to $36 \mu \mathrm{M}$ and $3.95 \mu \mathrm{M}$ to $35.3 \mu \mathrm{M}$, respectively. In addition, mansorin- $\mathrm{B}$, mansorin- $\mathrm{C}$, mansorin-II and mansorin-III significantly increased cellular entrapment of the P-glycoprotein (P-gp) substrate, doxorubicin, in colorectal cancer cells expressing the P-gp pump. The inhibitory effect of the isolated compounds on P-gp pump was examined using human recombinant P-gp molecules attached to ATPase subunit. Mansorin-B and mansonone-G were found to inhibit the P-gp attached ATPase subunit. On the other hand, mansorin-C, mansorin-III and mansorin-II inhibited P-gp pump via dual action (P-gp related ATPase subunit inhibition and P-gp substrate binding site occupation). However, mansorin II was examined for its potential chemomodulatory effect to paclitaxel (PTX) against colorectal cancer cells (HCT-116 and CaCo-2). Mansorin-II significantly reduced the $\mathrm{IC}_{50}$ of PTX in HCT-116 cells from $27.9 \pm 10.2 \mathrm{nM}$ to $5.1 \pm 1.9 \mathrm{nM}$ (synergism with combination index of 0.44 ). Additionally, Mansorin-II significantly reduced the $\mathrm{IC}_{50}$ of PTX in CaCo-2 cells from $2.1 \pm 0.8 \mu \mathrm{M}$ to $0.13 \pm 0.03 \mu \mathrm{M}$ (synergism with combination index of 0.18). Furthermore, cell cycle analysis was studied after combination of mansorin-II with paclitaxel using DNA flow cytometry analysis. Synergism of mansorin-II and PTX was reflected in increasing apoptotic cell population in both HCT-116 and CaCo-2 cells compared to PTX treatment alone. Combination of mansorin-II with PTX in CaCo-2 cells significantly increased the cell population in $\mathrm{G}_{2} / \mathrm{M}$ phase (from $2.9 \pm 0.3 \%$ to $7.7 \pm 0.8 \%$ ) with reciprocal decrease in $\mathrm{G}_{0} / \mathrm{G} 1$ cell fraction from $52.1 \pm 1.1 \%$ to $45.5 \pm 1.0 \%$. Similarly in HCT-116 cells, mansorin-II with PTX significantly increased the cell population in $\mathrm{G}_{2} / \mathrm{M}$ phase (from $33.4 \pm 2.8 \%$ to $37.6 \pm 1.3 \%$ ) with reciprocal decrease in the S-phase cell population from $22.8 \pm 1.7 \%$ to $20.2 \pm 0.8 \%$. In conclusion, mansorin-II synergizes the anticancer effect of paclitaxel in colorectal cancer cells, which might be partially attributed to enhancing its cellular entrapment via inhibiting P-gp efflux pump.
\end{abstract}


Keywords: O-naphthoquinones; coumarins; mansorin-II; paclitaxel; Mansonia gagei; colorectal cancer; P-glycoprotein; cell cycle

PACS: J0101

\section{Introduction}

Naphthoquinones are a group of widely distributed phenolics of plant origin and are classified to ortho and para-naphthoquinones. Ortho-naphthoquinones are particularly known for their cytotoxic effects among other biological activities such as anti-bacterial, anti-fungal and antiparasitic and acetylcholine esterase inhibitory effects [1]. Mansonones are a group of sesquiterpene-derived ortho-naphthoquinones occurring in different genuses in the plant kingdom such as Hibiscus, Mansonia and Thespesia [2]. Mansonones are, biosynthetically, thought to be phytoalexins produced by the injury of bark of some plants such as American elm (Ulmus minor). Mansonones E and F were reported to possess a potent cytotoxic effect on HeLa, human malignant melanoma A357-S2, MCF-7 and human histocytic lymphoma U937 cell lines [3,4]. In addition, antileukemic and topoisomerase inhibitory effects were reported to mansonone E. However, other mansonones such as mansones A-D, G, I-S were not investigated for their possible cytotoxic effects on several cell lines despite their structural similarity to that of mansones E and F [5].

Coumarins are naturally occurring benzopyrones with wide biological activities reported such as anti-inflammatory, antibacterial, cytotoxic, antioxidant and anti HIV effects [6]. Several naturally occurring coumarins and their synthetic derivatives exhibited cytotoxic effects via a telomerase enzyme inhibitory effect, protein kinases inhibition and oncogene downregulation. Other suggested cytotoxic mechanisms of coumarins are induction of caspase-9-mediated apoptosis and antiproliferative effects due to cell cycle arrest in $\mathrm{G}_{0} / \mathrm{G}_{1}$-phase and $\mathrm{G}_{2} / \mathrm{M}$-phase [7,8]. Finally, coumarins are expected to inhibit the efflux activity of p-glycoprotein (P-gp) and enhance the anticancer properties of several P-gp substrate chemotherapies [9].

Mansonia gagei is a tree belonging to the family Sterculiaceae and native to Thailand [10]. M. gagei heartwood was reported as a folk remedy for cardiac stimulation, anti-emetic, antidepressant and refreshing agent [11]. Several $O$-naphthoquinones named mansonones were isolated from this plant. In addition, a group of unique coumarins (Mansorin A-C and I-III), which are structurally related to mansonones, were also isolated from M. gagei. Mansonones and mansorins obtained from M. gagei revealed anti-estrogenic, larvicidal, antioxidant and antifungal activities [12-16]. Despite there are some reports about the cytotoxic effects of mansonones, there is nothing reported regarding the cytotoxicity of coumarins from this plant. Herein, we tested the potential cytotoxic effects of $O$-naphthoquinones and related coumarins from M. gagei against four different types of solid tumor cells. Among them, mansorin-II was further investigated for potential chemomodulatory effect to paclitaxel against colorectal cancer cells.

\section{Results and Discussion}

\subsection{Isolation and Structural Identification of O-Naphthoquinones and Coumarins}

The $\mathrm{CHCl}_{3}$-soluble fraction of $M$. gagie was subjected to several chromatographic processes using normal and reversed phase silica gel columns to obtain 7 compounds (1, 3-8) (Figure 1). In addition, compound 2 was obtained from its closely related 1 by demethylation using hydroiodic acid (Figure 1). The compounds were identified as six coumarins; mansorin A (1), mansorin B (2), mansorin C (3) [13], mansorin I (4), mansorin II (7) and mansorin III (8) [16], and, in addition to two sesqueterpenoid naphthoquinones, mansonone G (5) [17], and mansonone $\mathrm{N}$ (6) [15]. Compounds were identified by comparing its ${ }^{1} \mathrm{H}$ and ${ }^{13} \mathrm{C}-\mathrm{NMR}$ data with the reported literature (Supplementary Materials Figures S5-S12). 
<smiles>COc1cc(C)c2oc(=O)c(C)cc2c1C(C)C</smiles>

1<smiles>CC1=Cc2c(c(C)cc(O)c2C(C)C)C(=O)C1=O</smiles><smiles>Cc1cc2c(C(C)C)c(O)cc(C)c2oc1=O</smiles>

2<smiles>COc1c(C)cc2c(c1O)[C@H](C)CC(=O)[C@]2(O)C(C)C</smiles><smiles></smiles>

3<smiles>COc1cc(C)c2oc(=O)c(C)c3c2c1[C@H](C)CO3</smiles><smiles>CC1=C2c3c(c(C)cc(O)c3C1=O)OC[C@H]2C</smiles>

4<smiles>Cc1ccc2c(C)ccc3c2c1OC[C@]3(C)O</smiles>

8

Figure 1. Compounds isolated from the heartwood of M. gagie Drumm.

\subsection{Cytotoxicity Assessment of Some O-Naphthoquinones and Coumarins}

SRB-U assay was used to assess the cytotoxicity of eight naturally naphthoquinone and related coumarin compounds against four different tumor cell lines over concentration range 0.01-100 $\mu \mathrm{M}$. Tested compounds showed variable cytotoxicity against cell lines under investigation (HCT-116, HepG2, MCF-7 and HeLa cell lines) (Supplementary Materials Figures S1-S4). However, MCF-7 was relatively more resistant while HeLa was the most sensitive cell line under investigation (Table 1).

Table 1. Cytotoxicity parameters of some naturally occurring coumarins and $O$-naphthoquinones against different solid tumor cell lines.

\begin{tabular}{|c|c|c|c|c|c|c|c|c|}
\hline \multirow[b]{2}{*}{ Compound } & \multicolumn{2}{|c|}{ HCT-116 } & \multicolumn{2}{|c|}{ HepG2 } & \multicolumn{2}{|c|}{ MCF-7 } & \multicolumn{2}{|c|}{ HeLa } \\
\hline & $\begin{array}{l}\mathrm{IC}_{50} \\
(\mu \mathrm{M})\end{array}$ & $\begin{array}{c}\text { R-Fraction } \\
(\%)\end{array}$ & $\begin{array}{l}\mathrm{IC}_{50} \\
(\mu \mathrm{M})\end{array}$ & $\begin{array}{c}\text { R-Fraction } \\
(\%)\end{array}$ & $\begin{array}{l}\mathrm{IC}_{50} \\
(\mu \mathrm{M})\end{array}$ & $\begin{array}{c}\text { R-Fraction } \\
(\%)\end{array}$ & $\begin{array}{l}\mathrm{IC}_{50} \\
(\mu \mathrm{M})\end{array}$ & $\begin{array}{c}\text { R-Fraction } \\
(\%)\end{array}$ \\
\hline Mansorin-A (1) & 11.2 & 0.0 & 3.9 & 46.5 & 2.1 & 90.5 & 12.3 & 1.5 \\
\hline Mansorin-B (2) & 5.7 & 26.3 & 21.9 & 0.0 & 5.0 & 78.9 & 38.7 & 1.3 \\
\hline Mansorin-C (3) & 8.6 & 49.9 & 12.1 & 31.3 & 3.1 & 77.2 & 1.0 & 3.5 \\
\hline Mansorin-I (4) & 11.1 & 0.0 & 35.3 & 0.0 & 23.8 & 0.0 & 3.95 & 0.0 \\
\hline Mansorin-II (7) & 19.3 & 0.36 & 26.8 & 0.0 & 36.0 & 0.0 & 0.74 & 5.7 \\
\hline Mansorin III (8) & $>100$ & 0.0 & 7.2 & 69.6 & $>100$ & 0.0 & 5.2 & 39.8 \\
\hline Mansonone-G (5) & 63.4 & 0.5 & 49.4 & 1.1 & 23.0 & 5.1 & 18.8 & 1.8 \\
\hline Mansonone-N (6) & $>100$ & 0.0 & $>100$ & 5.2 & $>100$ & 97.2 & $>100$ & 0.0 \\
\hline
\end{tabular}

In HCT-116 colorectal cancer cells, mansorin-A, mansorin-I and mansorin-II showed the most potent cytotoxic profile with R-values less than $20 \%$ and $\mathrm{IC}_{50} \mathrm{~s}$ of $11.2 \mu \mathrm{M}, 11.1 \mu \mathrm{M}$ and $19.3 \mu \mathrm{M}$, respectively. Mansonone-G, mansonone- $\mathrm{N}$ and mansorin-III possessed relatively weaker cytotoxic profile with $\mathrm{IC}_{50}$ s higher than $50 \mu \mathrm{M}$. With respect to mansorin-B and mansorin-C, despite their apparent high potencies ( $\mathrm{IC}_{50} \mathrm{~s}$ of $5.7 \mu \mathrm{M}$ and $8.6 \mu \mathrm{M}$, respectively), their R-values were higher than $20 \%$ ( $26.3 \%$ and $49.9 \%$, respectively). It was found in our previous work that decreasing the R-value percent is an indicator of diminishing colorectal cancer cell resistance due to the overexpression of the P-glycoprotein efflux pump [18].

In HepG2 liver cancer cells, mansorin-B, mansorin I, mansonone-G and mansorin II showed relatively potent cytotoxic profile at an R-value less than $20 \%$ and $\mathrm{IC}_{50} \mathrm{~s}$ ranging from $21.9 \mu \mathrm{M}$ to $49.4 \mu \mathrm{M}$. Mansonone-N showed weak cytotoxicity with $\mathrm{IC}_{50}$ higher than $100 \mu \mathrm{M}$. However, the R-value of mansonone- $\mathrm{N}$ was relatively low (5.2\%). On the other hand, mansorin- $\mathrm{A}$, mansorin- $\mathrm{C}$ and mansorin III suffered from high cellular resistance in HepG2 cells (R-values were higher than 30\%). Similar to colorectal cancer cells, liver cancer might express P-gp pump [19]. In addition, other underlying reasons 
for liver cancer cell resistance are reported such as tumor-associated stem cells [20], overexpression of oncogenes and/or downregulation of tumor suppressor genes [21].

With respect to MCF-7 breast cancer cells, mansorin I, mansonone-G and mansorin II showed considerable cytotoxicity with $\mathrm{IC}_{50} \mathrm{~S}$ of $23.8 \mu \mathrm{M}, 23.0 \mu \mathrm{M}$ and $36.0 \mu \mathrm{M}$, respectively (R-values were less than $20 \%$ ). Mansonone-N and mansorin I showed weak cytotoxicity with $\mathrm{IC}_{50}$ higher than $100 \mu \mathrm{M}$. Other compounds (mansorin-A, mansorin-B and mansorin-C) showed apparently low $\mathrm{IC}_{50} \mathrm{~s}(2.1 \mu \mathrm{M}$, $5.0 \mu \mathrm{M}$ and $3.1 \mu \mathrm{M}$, respectively) with very high resistance (R-values were higher than $70 \%$ ).

The most sensitive cell line to $O$-naphthoquinones and related coumarins under investigation was HeLa cells; mansorin-A, mansorin-B, mansorin-C, mansorin II, mansorin-I, and mansonone-G killed HeLa cells with $\mathrm{IC}_{50}$ s less than $50 \mu \mathrm{M}$ and R-values less than $10 \%$. Only mansonone-N did not show any cytotoxicity against HeLa cells with $\mathrm{IC}_{50}$ higher that $100 \mu \mathrm{M}$ and mansorin-III suffered from resistant fraction higher than $30 \%$. Structurally related coumarins are known to induce apoptosis and cell cycle arrest in cervical cancer cells such as HeLa cells [22].

Accordingly, mansorin-I and mansorin-II would be recommended for further investigations either as cytotoxic or cytotoxicity chemomodulating agent. It is worth mentioning that coumarins are known for their cytotoxic potential due to their non-covalent DNA binding ability [23].

\subsection{The Influence of O-Naphthoquinones and Related Coumarins on the Cellular Pharmacokinetics within Tumor Cells}

Multidrug resistance in particular tumor types, such as solid tumors within the gastrointestinal tract, is highly attributed to impaired cellular pharmacokinetics and intracellular drug entrapment issues [24]. The ability of $O$-naphthoquinones and related coumarins to enhance the cellular entrapment of P-glycoprotein substrates was tested within HCT-116 colorectal cells. Mansorin-II, mansorin-B, mansorin- $\mathrm{C}$ and mansorin-I significantly increased cellular internalization of doxorubicin (P-gp probe) and significantly increased its intracellular concentration from $5.37 \pm 0.17 \mathrm{nmole} / \mathrm{cell}$ to $5.78 \pm 0.19 \mathrm{nmole} /$ cell, $5.55 \pm 0.13 \mathrm{nmole} /$ cell, $5.8 \pm 0.14 \mathrm{nmole} /$ cell and $5.78 \pm 0.19 \mathrm{nmole} /$ cell, respectively. On the other hand, mansorin-A decreased the intracellular concentration of doxorubicin to $5.01 \pm 0.12 \mathrm{nmole} /$ cell (Figure 2A). HCT-116 and other colorectal cancer cells are known to express P-gp efflux protein and participate considerably in their resistance to chemotherapies [18,25].

Further investigation for the sub-molecular interaction between the isolated compounds and P-gp subunits was undertaken using human recombinant P-gp membrane bound protein linked to ATPase enzyme subunits. P-gp binding site inhibitors such as verapamil (VRP) are supposed to increase ATPase activity due to conformational changes and results in more ATP consumption $(68.7 \%$ less remaining ATP concentration compared to basal ATP consumption). On the other hand, direct ATPase enzyme subunit inhibitors such as sodium vanadate would decrease ATP consumption (203.7\% more remaining ATP concentration compared to basal consumption condition). Only mansorin-B and mansonone-G showed pure ATPase inhibitory effects with $155.6 \%$ and $137.0 \%$ more remaining ATP concentration, respectively (Figure 2B). Other naphthoquinones and coumarins did not induce any significant change for ATP consumption rate. This might be attributed to lack of interaction with either subunit of P-gp molecules or attributed to dual interaction with both subunits. However, mansorin-II, mansorin-C and mansorin-I significantly increased cellular entrapment of P-gp probe. Accordingly, it is suggested that mansorin-II, mansorin-C and mansorin-I interact with both subunits of P-gp molecules. On the other hand, mansorin-A, mansonone-N and mansorin-III did not exert any significant interaction with either subunits of P-gp molecules. Our previous work on synthetic compounds based on curcumin scaffold showed a distinct ATPase inhibitory effect and/or binding site inhibition effect. This, in turn, increased the efficacy and decreased the resistance to paclitaxel within colorectal cancer cells [18]. Many other P-gp inhibitors of synthetic origin were suggested as potential chemomodulators of several anticancer drugs [26-29]. Herein, a similar chemomodulatory effect is expected when combining compounds such as mansorin-II with P-gp substrate (such as paclitaxel) [30]. However, several compounds of natural origin are known for their P-gp inhibitory 
potential and hence chemomodulatory capacity due to improving the cellular pharmacokinetics of anticancer agents $[9,31,32]$.

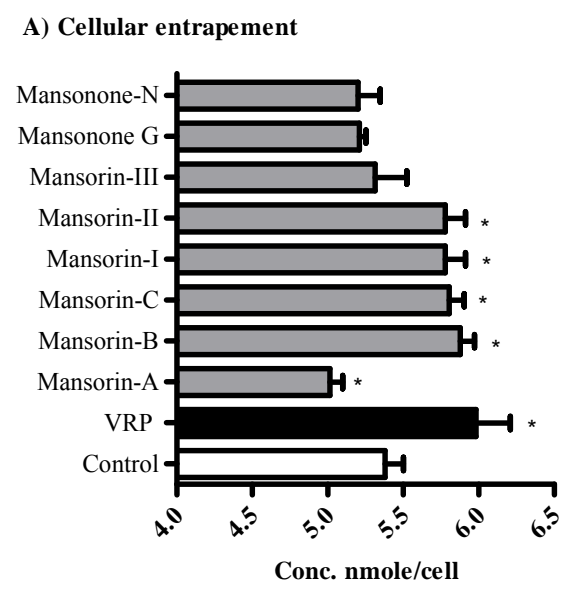

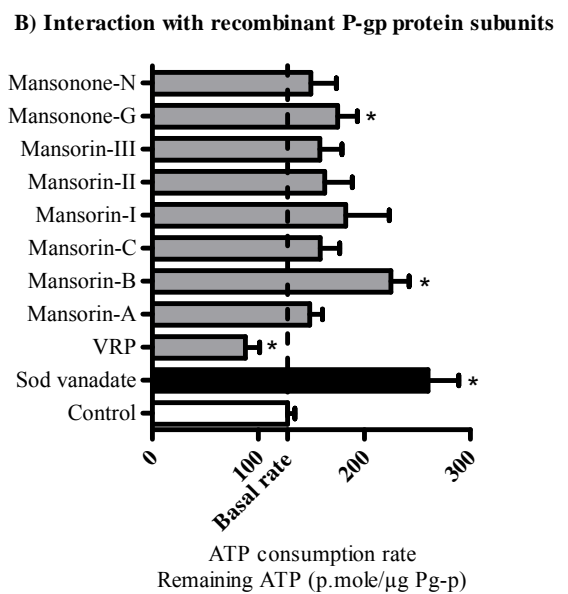

Figure 2. The effect of isolated compounds on the activity of P-glycoprotein efflux pump within HCT-116 cells (A) and in cell free isolated recombinant P-gp protein (B). Data is presented as mean $\pm \mathrm{SD} ; n=3$. $\left({ }^{*}\right)$ : significantly different from $\mathrm{CCl}_{4}$ treated group.

\subsection{Chemomodulatory Effect of Mansorin-II to Paclitaxel (PTX) against Colorectal Cancer Cells}

P-gp efflux activity is a considerable determinant for paclitaxel intracellular pharmacokinetics and hence cell killing effect $[30,33]$. Attributed to its considerable cytotoxic profile and its P-gp interaction properties, mansorin-II would be a good candidate to improve the activity of P-gp substrate drugs (such as paclitaxel) within P-gp expressing tumor cell types (such as colorectal cancer). Cytotoxicity of mansorin-II was much weaker in CaCo-2 cells compared to HCT-116 cells with $\mathrm{IC}_{50}$ s of $107.9 \pm 6.4 \mu \mathrm{M}$ and $19.3 \pm 3.7 \mu \mathrm{M}$, respectively. However, mansorin-II synergistically improved the cytotoxic profile of PTX against both colorectal cancer cell lines. Mansorin-II significantly decreased the $\mathrm{IC}_{50} \mathrm{~s}$ of PTX form $27.9 \pm 10.2 \mathrm{nM}$ and $2.1 \pm 0.8 \mu \mathrm{M}$ to $5.1 \pm 1.9 \mathrm{nM}$ and $0.13 \pm 0.03 \mu \mathrm{M}$ in HCT-116 and CaCo- 2 cells, respectively (Figure 3A,B). The combination indices for equitoxic combination of mansorin-II and PTX within HCT-116 and CaCo-2 cells were 0.44 and 0.18, respectively. In addition, mansorin-II decreased the resistant fraction to PTX within HCT-116 and CaCo-2 cells from $14.2 \pm 5.3 \%$ and $3.1 \pm 0.37 \%$ to $11.6 \pm 6.3 \%$ and $1.8 \pm 0.25 \%$, respectively (Table 2 ). As shown in our previous work, inhibiting P-gp ATPase subunit would decrease tumor cell resistance, while binding site inhibition increased anticancer potency (decreased $\mathrm{IC}_{50}$ ) [18].
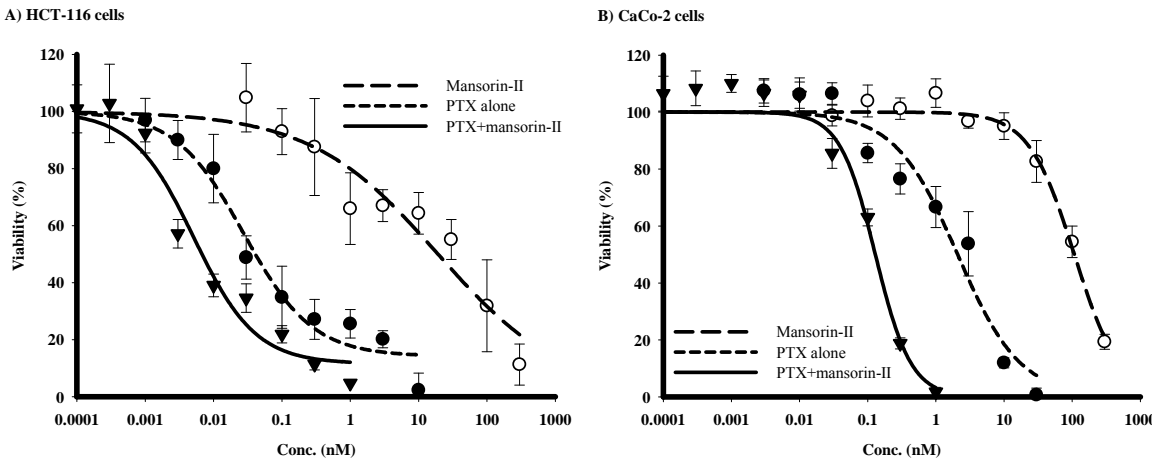

Figure 3. The effect of mansorin-II on the cytotoxicity of PTX in HCT-116 (A) and CaCo-2 (B) cell lines. Cells were exposed to serial dilution of $\operatorname{PTX}(\bullet)$, mansorin-II $(\bigcirc)$ or their combination $(\boldsymbol{\nabla})$ for $72 \mathrm{~h}$. Cell viability was determined using SRB assay. 
Table 2. Effect of mansorin-II on the cytotoxicity parameters of PTX in colorectal cancer cell lines.

\begin{tabular}{ccccc}
\hline & \multicolumn{2}{c}{ HCT-116 } & \multicolumn{2}{c}{ CaCo-2 } \\
\cline { 2 - 5 } & IC $_{\mathbf{5 0}}$ & R-Value (\%) & IC $_{\mathbf{5 0}}$ & R-Value (\%) \\
\hline PTX & $27.9 \pm 10.2 \mathrm{nM}$ & $14.2 \pm 5.3$ & $2.1 \pm 0.8 \mu \mathrm{M}$ & $3.1 \pm 0.37$ \\
Mansorin-II & $19.3 \pm 3.7 \mu \mathrm{M}$ & $0.36 \pm 0.007$ & $107.9 \pm 6.4 \mu \mathrm{M}$ & $0.34 \pm 0.004$ \\
PTX with mansorin-II & $5.1 \pm 1.9 \mathrm{nM}$ & $11.6 \pm 6.3$ & $0.13 \pm 0.03 \mu \mathrm{M}$ & $1.8 \pm 0.25$ \\
\hline CI-index/CI-value & \multicolumn{2}{c}{ Synergism/0.44 } & \multicolumn{2}{c}{ Synergism/0.18 } \\
\hline
\end{tabular}

\subsection{Cell Cycle Distribution Analysis of Colorectal Cancer Cells}

Cell cycle distribution using DNA flow cytometry was used to investigate the nature of interaction between PTX and mansorin-II. Cell cycle analysis can figure out or dissect the antiproliferative effect of PTX, mansorin-II or their combination in terms of cell cycle phase specificity $\left(G_{0} / G_{1}, S\right.$ and $\mathrm{G}_{2} / \mathrm{M}$-phases) [34]. In addition, it gives considerable clues for potential cell killing effects by assessing cell population in the pre-G phase [35]. In CaCo-2 cells, mansorin II significantly increased cell population is S-phase from $22.4 \pm 1.4 \%$ to $29.9 \pm 0.6 \%$ with reciprocal decrease $\mathrm{inG}_{2} / \mathrm{M}$ cell population (Figure $4 \mathrm{~A}, \mathrm{~B}, \mathrm{E})$. Suboptimal exposure ( $24 \mathrm{~h}$ ) to PTX alone did not exert any significant change in the cell cycle distribution pattern of CaCo-2 cells (Figure 4A,C,E). Combination of PTX with mansorin-II induced significant cell cycle arrest at $\mathrm{G}_{2} / \mathrm{M}$ phase $(11.2 \pm 0.7 \%)$ compared to control or PTX treatment alone ( $4.0 \pm 0.3 \%$ and $4.2 \pm 0.4 \%$, respectively). The induced $\mathrm{G}_{2} / \mathrm{M}$ cell phase arrest was accompanied by reciprocal decrease in the non-proliferating cell population $\left(\mathrm{G}_{0} / \mathrm{G}_{1}\right.$-phase) from $73.4 \pm 1.1 \%$ to $66.8 \pm 0.8 \%$ (Figure $4 \mathrm{~A}, \mathrm{C}-\mathrm{E}$ ). Finally, exposure of $\mathrm{CaCo}-2$ cells to PTX for $24 \mathrm{~h}$ resulted in significant cell death observed by elevated pre-G cell population form $2.9 \pm 1.1 \%$ to $27.8 \pm 0.9 \%$. Combination of PTX with mansorin-II further increased pre-G cell population to $31.9 \pm 0.3 \%$ (Figure $4 \mathrm{~F}$ ).
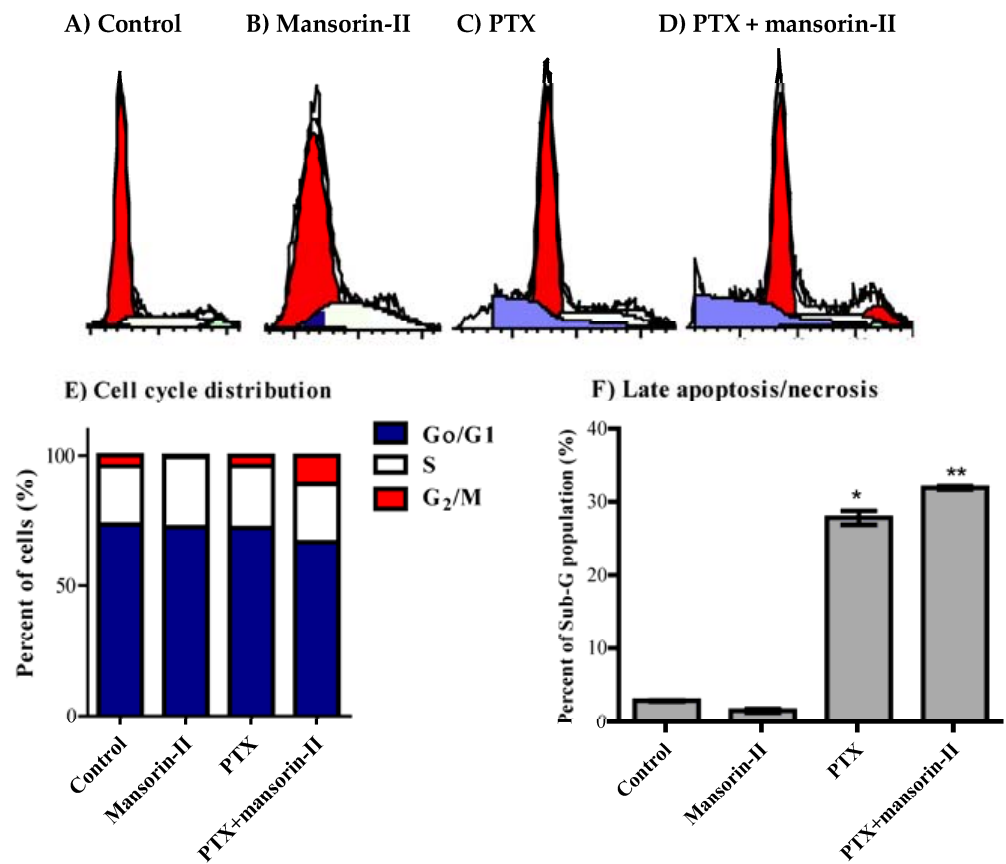

Figure 4. Effect of mansorin II on the cell cycle distribution of CaCo-2 cells. The cells were exposed to mansorin II (B), PTX (C), or combination of mansorin II and PTX (D) for $24 \mathrm{~h}$ and compared to control cells (A). Cell cycle distribution was determined using DNA cytometry analysis and different cell phases were plotted (E) as percentage of total events. Sub-G cell population was taken as representative of late apoptosis/necrosis and was plotted as percent of total events $(\mathbf{F})$. Data is presented as mean \pm SD; $n=3$. $\left(^{*}\right)$ : significantly different from control group; $\left(^{* *}\right)$ : significantly different from PTX group. 
With respect to HCT-116, mansorin-II significantly decreased cell population is S-phase from $29.0 \pm 0.4 \%$ to $27.3 \pm 0.7 \%$ with reciprocal apparent increase in $\mathrm{G}_{2} / \mathrm{M}$ cell population from $23.1 \pm 0.5 \%$ to $25.0 \pm 0.9 \%$ (Figure 5A,B,E). PTX alone significantly induced cell cycle arrest at $\mathrm{G}_{2} / \mathrm{M}$-phase $(33.4 \pm 1.6 \%)$ with reciprocal decrease in both S-phase and $\mathrm{G}_{0} / \mathrm{G} 1$-phase from $29.0 \pm 0.4 \%$ to $22.8 \pm 1.0 \%$ and from $47.8 \pm 0.8 \%$ to $43.8 \pm 0.9 \%$, respectively (Figure $5 \mathrm{~A}, \mathrm{C}, \mathrm{E}$ ). Combination of mansorin II with PTX further increased cell accumulation in $\mathrm{G}_{2} / \mathrm{M}$ phase up to $37.6 \pm 0.8 \%$ with further reciprocal decrease in S-phase to $20.2 \pm 0.4 \%$ (Figure 5A,D,E). Finally, exposure of HCT-116 cells to PTX for $24 \mathrm{~h}$ resulted in significant cell death observed by elevated pre-G cell population form $0.2 \pm 0.01 \%$ to $1.7 \pm 0.1 \%$. Combination of PTX with mansorin II further increased pre-G cell population to $2.4 \pm 0.1 \%$ (Figure $5 \mathrm{~F}$ ).

Coumarins were found to induce cell cycle arrest and cell killing effect in tumor cells [22]. Herein, mansorin-II potentiated the PTX-dependent cell cycle arrest and cell killing effects. Despite some reports for the potential anticancer properties of natural and synthetic mansorins [36-38], to the best of our knowledge, this is the first report for anticancer chemotherapeutic and chemomodulatory effect of mansorin-II.

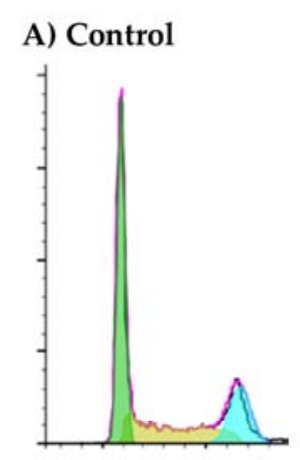

E) Cell cycle distribution

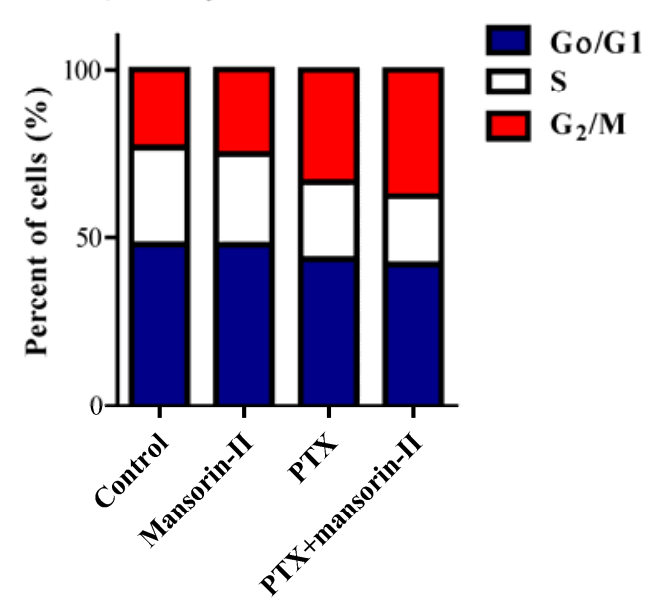

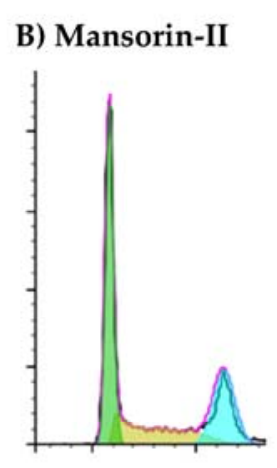

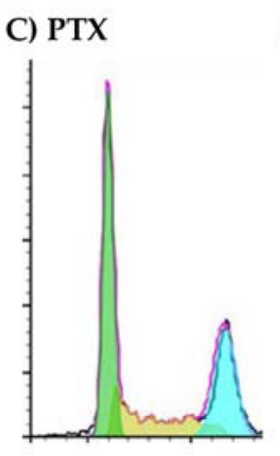

D) PTX + mansorin-II

F) Late apoptosis/necrosis

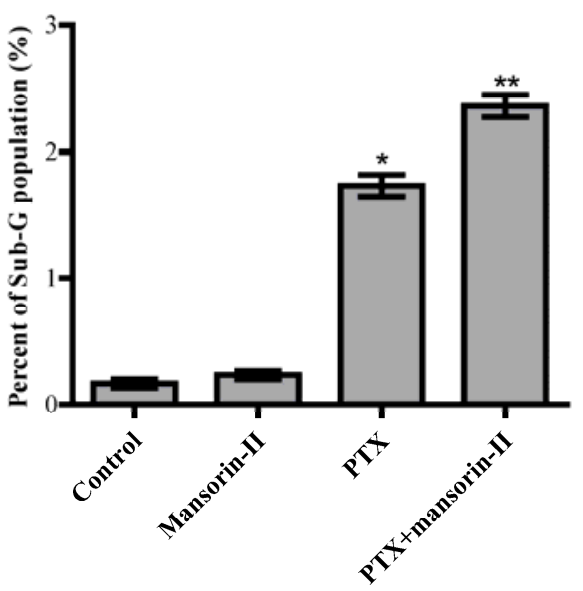

Figure 5. Effect of mansorin II on the cell cycle distribution of HCT-116 cells. The cells were exposed to mansorin II (B), PTX (C), or combination of mansorin II and PTX (D) for $24 \mathrm{~h}$ and compared to control cells (A). Cell cycle distribution was determined using DNA cytometry analysis and different cell phases were plotted (E) as percentage of total events. Sub-G cell population was taken as representative of late apoptosis/necrosis and was plotted as percent of total events (F). Data is presented as mean \pm SD; $n=3$. $\left({ }^{*}\right)$ : significantly different from control group; $(* *)$ : significantly different from PTX group. 


\section{Materials and Methods}

\subsection{Drugs and Chemicals}

Verapamil (VRP), trypan blue and Sulforhodamine-B (SRB) were purchased from Sigma Chemical Co. (St. Louis, MO, USA). Phosphate buffer saline (PBS) was purchased from Becton Dickinson (Fullerton, CA, USA). Penicillin/streptomycin and trypsin, RPMI-1640 media, DMEM media, fetal bovine serum (FBS), and other cell culture materials were purchased from Gibco (Grand Island, NY, USA). Other reagents were of the highest analytical grade.

\subsection{General Experimental Procedures}

TLC analysis was performed on pre-coated TLC plates with silica gel $60 \mathrm{~F}_{254}$ (Merck, Darmstadt, Germany). Column chromatographic separations were performed on silica gel 60 (70-230 mesh, Merck, Darmstadt, Germany). ${ }^{1} \mathrm{H}$ and ${ }^{13} \mathrm{C}-\mathrm{NMR}$ spectra were recorded on a Bruker DRX-850 MHz Ultrashield spectrometer (Bruker BioSpin, Billerica, MA, USA) using $\mathrm{CDCl}_{3}$ as solvent, with TMS as the internal reference. Medium pressure liquid chromatography (MPLC) was performed on LiChroprep RP-18 and LiChroprep Si 60 (size A and B, Merck Co., Kenilworth, NJ, USA).

\subsection{Plant Material}

The heartwood of Mansonia gagei Drumm was bought from the herbal drugstore "Cho Krom Pur," Bangkok, Thailand, and was identified by Dr. Katsuko Komatsu (Institute of Natural Medicine, University of Toyama, Toyama, Japan). A voucher specimen has been kept in the herbarium of the Institute of Natural Medicine, University of Toyama, Japan.

\subsection{Extraction and Isolation of Compounds from A. melegueta}

The mansonones and mansorins were isolated as previously described [16]. The dried powdered heartwood of M. gagei $(3.5 \mathrm{~kg}$ ) was extracted with methanol on cold. The methanol extract (250 g) was suspended in water $(500 \mathrm{~mL})$ and partitioned with chloroform $(1 \mathrm{~L} \times 3)$ and the pooled chloroform fractions were evaporated under vacuum. The combined chloroform fraction $(100 \mathrm{~g})$ was fractionated on a silica gel column $(70 \mathrm{~cm} \times 8 \mathrm{~cm})$ eluted with hexane-acetone $(5 \%$ until $80 \% v / v)$ to yield eight fractions. Fraction 1 (7 g) was applied to a silica gel column $(40 \mathrm{~cm} \times 4 \mathrm{~cm})$ eluted with hexane-ethyl acetate $(9.5: 0.5 \mathrm{v} / \mathrm{v})$ to obtain compound $1(4 \mathrm{~g})$. The remaining of fraction 1 was re-chromatographed using an MPLC silica gel 60 column (size A) (hexane-ethyl acetate, 9.5:0.5 v/v) to afford compounds 3 $(15 \mathrm{mg}), 6(30 \mathrm{mg})$ and $7(16 \mathrm{mg})$. Fraction $3(5.2 \mathrm{~g})$ was applied to a silica gel column $(40 \mathrm{~cm} \times 4 \mathrm{~cm})$ and eluted with hexane-ethyl acetate (9.5:0.5 9:1 v/v), then the eluate was pooled into three main sub-fractions. Fraction 3-2 was purified on a silica gel column $(20 \mathrm{~cm} \times 2.5 \mathrm{~cm})$ eluted with hexane-ethyl acetate $(9: 1 v / v)$ to obtain compound $5(2 \mathrm{~g})$. Fraction 3-3 was purified on an MPLC RP-18 column (size B) eluted with $\mathrm{MeOH}-\mathrm{H}_{2} \mathrm{O}(7: 3 \mathrm{v} / \mathrm{v})$ to get compound $4(7 \mathrm{mg})$ and $8(15 \mathrm{mg})$.

\subsection{Preparation of Compound 2}

Compound 1 (116 mg, $0.5 \mathrm{mmol})$ was dissolved in acetic anhydride $(5 \mathrm{~mL})$. Hydroiodic acid (HI) $(\mathrm{d}=1.7,2 \mathrm{~mL})$ was added to the previous solution with occasional shaking. The mixture was refluxed at $150{ }^{\circ} \mathrm{C}$ for $2 \mathrm{~h}$ in an oil bath. The resultant product was added to a saturated solution of sodium thiosulfate and extracted with ethyl acetate $(10 \mathrm{~mL} \times 3)$. The pooled ethyl acetate extracts were applied to a silica gel column using n-hexane-EtOAc $(9.5: 0.5 v / v)$ to obtain 2 as a yellowish white powder (91.5 mg) (74\%) [39].

\subsection{Cell Culture}

Five different human solid tumor cell lines were used; colorectal cancer cell lines (HCT-116 and CaCo-2), cervical cancer cell line (HeLa), hepatocellular canrcinoma cell line (HepG2), and breast 
adenocarcinoma cell line (MCF-7). All cell lines were obtained from VACSERA, Giza, Egypt. Cell lines were maintained in RPMI-1640 or DMEM media containing $100 \mathrm{U} / \mathrm{mL}$ penicillin; $100 \mu \mathrm{g} / \mathrm{mL}$ streptomycin, and supplemented with 10\% heat-inactivated fetal bovine serum (FBS). Cells were propagated in a humidified cell culture incubator with $5 \%(v / v) \mathrm{CO}_{2}$ at $37^{\circ} \mathrm{C}$.

\subsection{Cytotoxicity Assessment}

The cytotoxicity of the isolated compounds was tested against HCT-116, HeLa, HepG2, and MCF-7 cells by SRB assay as previously described [40]. Briefly, exponentially growing cells were collected using $0.25 \%$ Trypsin-EDTA and seeded in 96-well plates at 1000-2000 cells/well. Cells were treated with the isolated compounds for $72 \mathrm{~h}$ and subsequently fixed with trichloroacetic acid, TCA (10\%) for $1 \mathrm{~h}$ at $4{ }^{\circ} \mathrm{C}$. After several washings with water, cells were exposed to $0.4 \%$ SRB solution for $10 \mathrm{~min}$ at room temperature in a dark place and subsequently washed with $1 \%$ glacial acetic acid. After the plates dried overnight, Tris- $\mathrm{HCl}$ was used to dissolve the SRB stained cells. Color intensity was measured at $540 \mathrm{~nm}$ with SpectraMax ${ }^{\circledR}$ ELISA microplate reader (Molecular Devices LLC, San Jose, CA, USA).

\subsection{Data Analysis}

The dose-response curves were analyzed as previously described [41] using $\mathrm{E}_{\max }$ model (Equation (1)):

$$
\% \text { Cell viability }=(100-\mathrm{R}) \times\left(1-\frac{[\mathrm{D}]^{\mathrm{m}}}{\mathrm{K}_{\mathrm{d}}^{\mathrm{m}}+[\mathrm{D}]^{\mathrm{m}}}\right)+\mathrm{R},
$$

where $[R]$ is the residual unaffected fraction (the resistance fraction), [D] is the drug concentration used, $\left[\mathrm{K}_{\mathrm{d}}\right]$ or $\mathrm{IC}_{50}$ is the drug concentration that produces a $50 \%$ reduction of the maximum inhibition rate and $[\mathrm{m}]$ is a Hill-type coefficient. Absolute $\mathrm{IC}_{50}$ is defined as the drug concentration required to reduce absorbance by $50 \%$ of that of the control (i.e., $K_{d}=$ absolute $I_{50}$ when $R=0$ and $E_{\max }=100-R$ ).

\subsection{The Influence of Mansorin-II and Other O-Naphthoquinones/Coumarins on the Cellular Pharmacokinetics}

To assess the effect of mansorin-II and other naphthoquinones/coumarins on cellular pharmacokinetics in colorectal cancer cells, their effect on the efflux pumping activity of P-gp was evaluated. Herein, doxorubicin (DOX) was used as P-gp fluorescent substrate. Intracellular DOX concentration was determined with and without co-exposure with mansorin-II and other naphthoquinones/coumarins and compared to VRP as a standard P-gp inhibitor (positive control). Briefly, exponentially proliferating cells were plated in 6-well plates at plating density of $10^{5}$ cells/well. Cells were exposed to equimolar concentration of DOX $(10 \mu \mathrm{M})$ and test compounds or VRP for $24 \mathrm{~h}$ at $37^{\circ} \mathrm{C}$ and, subsequently, extracellular DOX-containing media was washed three times in ice cold PBS. Intracellular DOX was extracted after cell lysis by sonication with saturated aqueous solution of $\mathrm{ZnSO}_{4}(100 \mu \mathrm{L})$, acetonitril $(500 \mu \mathrm{L})$ and acetone $(250 \mu \mathrm{L})$ for $20 \mathrm{~min}$ at $37^{\circ} \mathrm{C}$. After centrifugation, clear supernatant solution was collected and DOX concentration was measured spectroflourometrically at $\lambda_{\mathrm{ex} / \mathrm{em}}$ of 482/550 nm. DOX concentration was normalized based on cell number [42].

\subsection{Determining Sub-Molecular Interaction Characteristics between P-gp Protein and O-Naphthoquinones/Coumarins}

P-gp inhibitors block its efflux pumping activity via either covalent binding or inhibiting P-gp ATPase activity. Human recombinant membrane bound P-gp protein attached with ATPase subunit (Pgp-Glo ${ }^{\mathrm{TM}}$ Assay Systems, Promega Corporation, Madison, WI, USA) was used as previously described to determine the mechanism of P-gp inhibition via determining ATP consumption rate $[18,25]$. Briefly, test compounds $(10 \mu \mathrm{M})$ were incubated with Pgp-Glo ${ }^{\mathrm{TM}}$ assay systems according to manufacturer's protocol. Rate of ATP consumption was calculated by measuring the luminescent signal of the unmetabolized ATP via a firefly luciferase system. Compounds whose covalents bind to P-gp substrate binding sites are supposed to stimulate ATPase subunits and increase ATP consumption, 
while ATPase inhibitor compounds would decrease ATPase subunit activity and decrease the ATP consumption rate. Verapamil and sodium vanadate were used as positive controls (binding site blocker and ATPase inhibitors, respectively). ATP consumption was expressed as remaining ATP concentration and normalized per P-gp protein concentration (p.mole ATP/ $\mu g$ P-gp protein).

\subsection{Chemomodulatory Effect of Mansorin-II to Paclitaxel within Colorectal Cancer Cells}

The chemomodulatory effect of mansorin-II to paclitaxel (PTX) within colorectal cancer cells was determined using combination analysis between PTX and mansorin II as previously described [43]. Briefly, exponentially growing HCT-116 and CaCo-2 cells were seeded in 96-well plates (2000 cells / well) and exposed to equitoxic concentrations of PTX and mansorin-II for $72 \mathrm{~h}$. Cells were subsequently subjected to SRB assay as described in the previous section. Combination index (CI-value) was calculated and used to define the nature of drug interaction (synergism if CI-value $<0.8$ as; antagonism if CI-value > 1.2; and additive if CI-value ranges from 0.8-1.2).

CI-value was calculated from the formula:

$$
C I-\text { value }=\frac{I C_{50} \circ f d r u g(x) \text { combination }}{I C_{50} \text { ofdrug }(x) \text { alone }}+\frac{I C_{50} \text { ofdrug }(y) \text { combination }}{I C_{50} \text { ofdrug }(y) \text { alone }} .
$$

\subsection{Analysis of Cell Cycle Distribution}

To assess the effect of the paclitaxel, mansorin-II and their combination on cell cycle distribution, CaCo-2 and HCT-116 cells were treated with the pre-determined $\mathrm{IC}_{50} \mathrm{~s}$ of both agents for $24 \mathrm{~h}$. After treatment, cells were collected by trypsinization, washed twice with ice-cold PBS and re-suspended in $0.5 \mathrm{~mL}$ of PBS. Two milliliters of 70\% ice-cold ethanol were added gently while vortexing. Cells were kept in ethanol solution at $4{ }^{\circ} \mathrm{C}$ for $1 \mathrm{~h}$ for fixation. Upon analysis, fixed cells were washed and re-suspended in $1 \mathrm{~mL}$ of PBS containing $50 \mu \mathrm{g} / \mathrm{mL}$ RNAase A and $10 \mu \mathrm{g} / \mathrm{mL}$ propidium iodide (PI). After $20 \mathrm{~min}$ incubation in a dark place at room temperature, $\mathrm{CaCo}-2$ cells were analyzed for DNA contents by FACS-VantageTM (Becton Dickinson Immunocytometry Systems, San Jose, CA, USA). For each sample, 10,000 events were acquired. Cell cycle distribution was calculated using CELLQuest software (Becton Dickinson Immunocytometry Systems) [44]. HCT-116 cells were injected through a ACEA Novocyte ${ }^{\mathrm{TM}}$ flow cytometer (ACEA Biosciences Inc., San Diego, CA, USA) and analyzed for DNA content using an FL2 signal detector $\left(\lambda_{\text {ex } / \mathrm{em}} 535 / 617 \mathrm{~nm}\right)$. For each sample, 12,000 events were acquired and quantified by ACEA NovoExpress ${ }^{\mathrm{TM}}$ software (ACEA Biosciences Inc., San Diego, CA, USA) [45].

\subsection{Statistical Analysis}

Data are presented as mean \pm SEM using GraphPad prism ${ }^{\mathrm{TM}}$ software (version 5.00, GraphPad software Inc., La Jolla, CA, USA) for Windows. Analysis of variance (ANOVA) with a Newman-Keuls post hoc test was used for testing the significance using SPSS ${ }^{\circledR}$ for Windows, version 17.0.0. (SPSS Inc., Chicago, IL, USA) $p<0.05$ was taken as a cut-off value for significance.

\section{Conclusions}

Mansorin-II (naturally occurring coumarin) synergizes the anticancer effect of paclitaxel. This synergism might be partly attributed to interfering with the efflux activity of the P-gp pump and/or interfering with cell cycle progression. Further mechanistic studies for the proposed intracellular targets of mansorin-II and related compounds are strongly recommended.

Supplementary Materials: The following are available online. Figure S1. Dose response curves of different naturally occurring $\mathrm{O}$-naphthoquinones and related coumarins against HCT-116 cells, Figure S2. Dose response curves of different naturally occurring $O$-naphthoquinones and related coumarins against HepG2 cells, Figure S3. Dose response curves of different naturally occurring O-naphthoquinones and related coumarins against MCF-7 cells, Figure S4. Dose response curves of different naturally occurring $O$-naphthoquinones and related coumarins against HeLa cells, Figure S5. ${ }^{1} \mathrm{H}$ - and ${ }^{13} \mathrm{C}-\mathrm{NMR}$ charts of compound 1, Figure S6. ${ }^{1} \mathrm{H}$ - and ${ }^{13} \mathrm{C}-\mathrm{NMR}$ charts of 
compound 2, Figure S7. ${ }^{1} \mathrm{H}$ and ${ }^{13} \mathrm{C}$ NMR charts of compound 3, Figure S8. ${ }^{1} \mathrm{H}$ - and ${ }^{13} \mathrm{C}-\mathrm{NMR}$ charts of compound 4, Figure S9. ${ }^{1} \mathrm{H}$ - and ${ }^{13} \mathrm{C}-\mathrm{NMR}$ charts of compound 5, Figure S10. ${ }^{1} \mathrm{H}$ and ${ }^{13} \mathrm{C}-\mathrm{NMR}$ charts of compound 6, Figure S11. ${ }^{1} \mathrm{H}$ - and ${ }^{13} \mathrm{C}$-NMR charts of compound 7, Figure S12. ${ }^{1} \mathrm{H}$ - and ${ }^{13} \mathrm{C}-\mathrm{NMR}$ charts of compound 8.

Author Contributions: A.M.A.-A. and A.M.E.-H. conceived and designed the experiments; M.A.B. performed the experiments; A.M.A.-A. and A.M.E.-H. analyzed the data; F.A.A.-A. contributed reagents/materials/analysis tools; A.M.A.-A. and A.M.E.-H. wrote the paper.

Acknowledgments: This project is funded by King Abdulaziz City of Science and Technology (KACST), Riyadh, Saudi Arabia, under Grant No. (AT-35-122). The authors, therefore, acknowledge with thanks KACST technical and financial support. The authors are indebted to Professor Masao Hattori, University of Toyama, Japan for providing the plant materials.

Conflicts of Interest: The authors declare no conflict of interest. The founding sponsors had no role in the design of the study; in the collection, analyses, or interpretation of data; in the writing of the manuscript, and in the decision to publish the results.

\section{Abbreviations}

The following abbreviations are used in this manuscript:

$\begin{array}{ll}\text { CI-value } & \text { Combination Index } \\ \text { DOX } & \text { Doxorubicin } \\ \text { FBS } & \text { Fetal bovine serum } \\ \text { P-gp } & \text { P-glycoprotein } \\ \text { PBS } & \text { Phosphate buffer saline } \\ \text { PTX } & \text { Paclitaxel } \\ \text { SRB } & \text { Sulforhodamine-B } \\ \text { VRP } & \text { Verapamil }\end{array}$

\section{References}

1. Hook, I.; Mills, C.; Sheridan, H. Bioactive naphthoquinones from higher plants. In Studies in Natural Products Chemistry; Elsevier: New York, NY, USA, 2014; Volume 41, pp. 119-160. ISBN 1572-5995.

2. Wu, P.-L.; Wu, T.-S.; He, C.-X.; Su, C.-H.; Lee, K.-H. Constituents from the stems of Hibiscus taiwanensis. Chem. Pharm. Bull. 2005, 53, 56-59. [CrossRef] [PubMed]

3. Wu, W.-B.; Ou, J.-B.; Huang, Z.-H.; Chen, S.-B.; Ou, T.-M.; Tan, J.-H.; Li, D.; Shen, L.-L.; Huang, S.-L.; Gu, L.-Q. Synthesis and evaluation of mansonone F derivatives as topoisomerase inhibitors. Eur. J. Med. Chem. 2011, 46, 3339-3347. [CrossRef] [PubMed]

4. Chen, Q.-F.; Liu, Z.-P.; Wang, F.-P. Natural sesquiterpenoids as cytotoxic anticancer agents. Mini Rev. Med. Chem. 2011, 11, 1153-1164. [CrossRef] [PubMed]

5. Wang, D.; Xia, M.; Cui, Z.; Tashiro, S.; Onodera, S.; Ikejima, T. Cytotoxic effects of mansonone E and F isolated from Ulmus pumila. Biol. Pharm. Bull. 2004, 27, 1025-1030. [CrossRef] [PubMed]

6. Klenkar, J.; Molnar, M. Natural and synthetic coumarins as potential anticancer agents. J. Chem. Pharm. Res. 2015, 7, 1223-1238.

7. Amin, K.M.; Eissa, A.A.M.; Abou-Seri, S.M.; Awadallah, F.M.; Hassan, G.S. Synthesis and biological evaluation of novel coumarin-pyrazoline hybrids endowed with phenylsulfonyl moiety as antitumor agents. Eur. J. Med. Chem. 2013, 60, 187-198. [CrossRef] [PubMed]

8. Nasr, T.; Bondock, S.; Youns, M. Anticancer activity of new coumarin substituted hydrazide-hydrazone derivatives. Eur. J. Med. Chem. 2014, 76, 539-548. [CrossRef] [PubMed]

9. Abdallah, H.M.; Al-Abd, A.M.; El-Dine, R.S.; El-Halawany, A.M. P-glycoprotein inhibitors of natural origin as potential tumor chemo-sensitizers: A review. J. Adv. Res. 2015, 6, 45-62. [CrossRef] [PubMed]

10. Braidy, N.; Poljak, A.; Jayasena, T.; Sachdev, P. Natural Plant-Derived Acetylcholinesterase Inhibitors: Relevance for Alzheimer's Disease. Nat. Prod. Target. Clin. Relevant Enzym. 2017, 297-318. [CrossRef]

11. Al Muqarrabun, L.M.R.; Ahmat, N. Medicinal uses, phytochemistry and pharmacology of family Sterculiaceae: A review. Eur. J. Med. Chem. 2015, 92, 514-530. [CrossRef] [PubMed]

12. Tiew, P.; Takayama, H.; Kitajima, M.; Aimi, N.; Kokpol, U.; Chavasiri, W. A novel neolignan, mansoxetane, and two new sesquiterpenes, mansonones R and S, from Mansonia gagei. Tetrahedron Lett. 2003, 44, 6759-6761. [CrossRef] 
13. Tiew, P.; Puntumchai, A.; Kokpol, U.; Chavasiri, W. Coumarins from the heartwoods of Mansonia gagei Drumm. Phytochemistry 2002, 60, 773-776. [CrossRef]

14. Tiew, P.; Ioset, J.; Kokpol, U.; Chavasiri, W.; Hostettmann, K. Antifungal, antioxidant and larvicidal activities of compounds isolated from the heartwood of Mansonia gagei. Phytother. Res. 2003, 17, 190-193. [CrossRef] [PubMed]

15. Tiew, P.; Ioset, J.-R.; Kokpol, U.; Schenk, K.; Jaiboon, N.; Chaichit, N.; Chavasiri, W.; Hostettmann, K. Four New Sesquiterpenoid Derivatives from the Heartwood of Mansonia g agei. J. Nat. Prod. 2002, 65, 1332-1335. [CrossRef] [PubMed]

16. El-Halawany, A.M.; Chung, M.H.; Ma, C.-M.; Komatsu, K.; Nishihara, T.; Hattori, M. Anti-estrogenic Activity of Mansorins and Mansonones from the Heartwood of Mansonia gagei DRUMM. Chem. Pharm. Bull. 2007, 55, 1332-1337. [CrossRef] [PubMed]

17. Galeffi, C.; delle Monache, E.M.; Casinovi, C.G.; Bettolo, G.B.M. A new quinone from the heartwood of Mansonia Altissima chev: Mansonone L. Tetrahedron Lett. 1969, 10, 3583-3584. [CrossRef]

18. El-Araby, M.E.; Omar, A.M.; Khayat, M.T.; Assiri, H.A.; Al-Abd, A.M. Molecular Mimics of Classic P-Glycoprotein Inhibitors as Multidrug Resistance Suppressors and Their Synergistic Effect on Paclitaxel. PLoS ONE 2017, 12, e0168938. [CrossRef] [PubMed]

19. Thiebaut, F.; Tsuruo, T.; Hamada, H.; Gottesman, M.M.; Pastan, I.; Willingham, M.C. Cellular localization of the multidrug-resistance gene product P-glycoprotein in normal human tissues. Proc. Natl. Acad. Sci. USA 1987, 84, 7735-7738. [CrossRef] [PubMed]

20. Sell, S.; Leffert, H.L. Liver cancer stem cells. J. Clin. Oncol. Off. J. Am. Soc. Clin. Oncol. 2008, 26, 2800. [CrossRef] [PubMed]

21. Gottesman, M.M. Mechanisms of cancer drug resistance. Annu. Rev. Med. 2002, 53, 615-627. [CrossRef] [PubMed]

22. Chuang, J.-Y.; Huang, Y.-F.; Lu, H.-F.; Ho, H.-C.; Yang, J.-S.; Li, T.-M.; Chang, N.-W.; Chung, J.-G. Coumarin induces cell cycle arrest and apoptosis in human cervical cancer HeLa cells through a mitochondria-and caspase-3 dependent mechanism and NF-kB down-regulation. In Vivo 2007, 21, 1003-1009. [PubMed]

23. Raju, G.; Srinivas, R.; Reddy, M.D.; Reddy, C.R.; Nagesh, N. Studies on non-covalent interaction of coumarin attached pyrimidine and 1-methyl indole 1, 2, 3 triazole analogues with intermolecular telomeric G-quadruplex DNA using ESI-MS and spectroscopy. Nucleosides Nucleotides Nucleic Acids 2014, 33, 489-506. [CrossRef] [PubMed]

24. Al-Abd, A.M.; Aljehani, Z.K.; Gazzaz, R.W.; Fakhri, S.H.; Jabbad, A.H.; Alahdal, A.M.; Torchilin, V.P. Pharmacokinetic strategies to improve drug penetration and entrapment within solid tumors. J. Control. Release 2015, 219, 269-277. [CrossRef] [PubMed]

25. Khaleel, S.A.; Al-Abd, A.M.; Ali, A.A.; Abdel-Naim, A.B. Didox and resveratrol sensitize colorectal cancer cells to doxorubicin via activating apoptosis and ameliorating P-glycoprotein activity. Sci. Rep. 2016, 6. [CrossRef] [PubMed]

26. Minderman, H.; O'Loughlin, K.L.; Pendyala, L.; Baer, M.R. VX-710 (biricodar) increases drug retention and enhances chemosensitivity in resistant cells overexpressing P-glycoprotein, multidrug resistance protein, and breast cancer resistance protein. Clin. Cancer Res. 2004, 10, 1826-1834. [CrossRef] [PubMed]

27. Walker, J.; Martin, C.; Callaghan, R. Inhibition of P-glycoprotein function by XR9576 in a solid tumour model can restore anticancer drug efficacy. Eur. J. Cancer 2004, 40, 594-605. [CrossRef] [PubMed]

28. Boesch, D.; Gaveriaux, C.; Jachez, B.; Pourtier-Manzanedo, A.; Bollinger, P.; Loor, F. In vivo circumvention of P-glycoprotein-mediated multidrug resistance of tumor cells with SDZ PSC 833. Cancer Res. 1991, 51, 4226-4233. [PubMed]

29. Newman, M.J.; Rodarte, J.C.; Benbatoul, K.D.; Romano, S.J.; Zhang, C.; Krane, S.; Moran, E.J.; Uyeda, R.T.; Dixon, R.; Guns, E.S.; et al. Discovery and characterization of OC144-093, a novel inhibitor of P-glycoprotein-mediated multidrug resistance. Cancer Res. 2000, 60, 2964-2972. [PubMed]

30. Jang, S.H.; Wientjes, M.G.; Au, J.L. Kinetics of P-glycoprotein-mediated efflux of paclitaxel. J. Pharmacol. Exp. Ther. 2001, 298, 1236-1242. [PubMed]

31. Zhang, Y.; Zhang, Y.K.; Wang, Y.J.; Vispute, S.G.; Jain, S.; Chen, Y.; Li, J.; Youssef, D.T.A.; El Sayed, K.A.; Chen, Z.S. Esters of the marine-derived triterpene sipholenol a reverse P-GP-mediated drug resistance. Mar. Drugs 2015, 13, 2267-2286. [CrossRef] [PubMed] 
32. Quan, F.; Pan, C.; Ma, Q.; Zhang, S.; Yan, L. Reversal effect of resveratrol on multidrug resistance in KBv200 cell line. Biomed. Pharmacother. 2008, 62, 622-629. [CrossRef] [PubMed]

33. Zhan, Z.; Scala, S.; Monks, A.; Hose, C.; Bates, S.; Fojo, T. Resistance to paclitaxel mediated by P-glycoprotein can be modulated by changes in the schedule of administration. Cancer Chemother. Pharmacol. 1997, 40, 245-250. [CrossRef] [PubMed]

34. Kuh, H.J.; Nakagawa, S.; Usuda, J.; Yamaoka, K.; Saijo, N.; Nishio, K. A computational model for quantitative analysis of cell cycle arrest and its contribution to overall growth inhibition by anticancer agents. Jpn. J. Cancer Res. 2000, 91, 1303-1313. [CrossRef] [PubMed]

35. Pucci, B.; Kasten, M.; Giordano, A. Cell cycle and apoptosis. Neoplasia 2000, 2, 291-299. [CrossRef] [PubMed]

36. Kostova, I. Synthetic and natural coumarins as cytotoxic agents. Curr. Med. Chem. Agents 2005, 5, $29-46$. [CrossRef]

37. Kostova, I.; Bhatia, S.; Grigorov, P.; Balkansky, S.; Parmar, V.S.; Prasad, A.K.; Saso, L. Coumarins as antioxidants. Curr. Med. Chem. 2011, 18, 3929-3951. [CrossRef] [PubMed]

38. Boonsri, S.; Karalai, C.; Ponglimanont, C.; Chantrapromma, S.; Kanjana-opas, A. Cytotoxic and antibacterial sesquiterpenes from Thespesia populnea. J. Nat. Prod. 2008, 71, 1173-1177. [CrossRef] [PubMed]

39. El-Halawany, A.M.; El Dine, R.S.; Hattori, M. Anti-estrogenic activity of mansonone G and mansorin A derivatives. Pharm. Biol. 2013, 51, 948-954. [CrossRef] [PubMed]

40. Skehan, P.; Storeng, R.; Scudiero, D.; Monks, A.; McMahon, J.; Vistica, D.; Warren, J.T.; Bokesch, H.; Kenney, S.; Boyd, M.R. New colorimetric cytotoxicity assay for anticancer-drug screening. J. Natl. Cancer Inst. 1990, 82, 1107-1112. [CrossRef] [PubMed]

41. Mahmoud, A.M.; Al-Abd, A.M.; Lightfoot, D.A.; El-Shemy, H.A. Anti-cancer characteristics of mevinolin against three different solid tumor cell lines was not solely p53-dependent. J. Enzyme Inhib. Med. Chem. 2012, 27. [CrossRef] [PubMed]

42. Al-Abd, A.M.; Mahmoud, A.M.; El-Sherbiny, G.A.; El-Moselhy, M.A.; Nofal, S.M.; El-Latif, H.A.; El-Eraky, W.I.; El-Shemy, H.A. Resveratrol enhances the cytotoxic profile of docetaxel and doxorubicin in solid tumour cell lines in vitro. Cell Prolif. 2011, 44. [CrossRef] [PubMed]

43. Chou, T.C.; Talalay, P. Quantitative analysis of dose-effect relationships: The combined effects of multiple drugs or enzyme inhibitors. Adv. Enzym. Regul. 1984, 22, 27-55. [CrossRef]

44. Nawwar, M.A.; Swilam, N.F.; Hashim, A.N.; Al-Abd, A.M.; Abdel-Naim, A.B.; Lindequist, U. Cytotoxic isoferulic acidamide from Myricaria germanica (Tamaricaceae). Plant Signal. Behav. 2013, 8. [CrossRef] [PubMed]

45. Mohamed, G.A.; Al-Abd, A.M.; El-Halawany, A.M.; Abdallah, H.M.; Ibrahim, S.R.M. New xanthones and cytotoxic constituents from Garcinia mangostana fruit hulls against human hepatocellular, breast, and colorectal cancer cell lines. J. Ethnopharmacol. 2017, 198, 302-312. [CrossRef] [PubMed]

Sample Availability: Samples of the all compounds mentioned in the manuscript are available from the authors.

(c) 2018 by the authors. Licensee MDPI, Basel, Switzerland. This article is an open access article distributed under the terms and conditions of the Creative Commons Attribution (CC BY) license (http:/ / creativecommons.org/licenses/by/4.0/). 